'The Magazine reports "Meteorological Records", by D. S. R. Wills, which is a summary of the local weather during October 1952-September 1953. In the bird-ringing work, 164 birds were ringed-125 from traps and 39 from nests. The Ornithological Section also gives a detailed analysis of nest record cards for 1953 (J. Beck), and an account of the birds of the Culmstock area. A paper entitled "A Study of the Influence of Light and Soil Properties on the Growth of Bracken" presents results of an excellent piece of field and experimental work by D. P. T. Burke. The realization that biology is the study of plants and animals living together in a community (rather than the uninspiring study of type specimens from books or, at most, dead bodies and pickle jars) comes out well in C. N. A. Clement's paper on "The Part Played by the Oak Tree in the Natural Plant and Animal Community of a Woodland". D. Knight Jones records some good experimental studies in his "Investigation of the Post-Floral Movements shown by the Garden Nasturtium". C. L. Honeybourne reports some "Observations on the Circulation of Nitrogen in the Grand Western Canal"; the field work here was carefully planned and carried out, and the observations include estimation of nitrogen in the water and of plankton. This excellent paper is accompanied by a table and two graphs. In the Spring Term of 1952, J. M. Saxon began some interesting observations on soil temperatures under natural conditions, using a thermistor.

Blundell's Magazine is a model of its kind and reflects great credit on the methods of science teaching in that School, for which Dr. M. Ashby, the biology master, is to be specially selected for congratulation.

\section{Fungi Pathogenic to Man and Animals}

A collection of fungi is maintained in the Laboratory of Mycology of the Institute Oswaldo Cruz (Caixa Postal 926, Rio de Janeiro, Brazil : List of Cultures, 1953). The workers in this laboratory are specially interested in the maintenance of cultures of fungi pathogenic to man and animals, though the list, which is a considerable one, contains many others, including plant pathogens. Scientists and institutions are asked to send cultures not included in the list. Cultures from the Institute's collection will be sent "to all institutions and scientists upon request and free of any charge".

\section{A New Modelling Medium}

A NEW modelling medium called 'Vinagel' is described in the November issue of the Museums Journal by Dr. H. F. Steedman, of the Zoology Department, University of Glasgow. At present it can be obtained in four grades, Nos. 116, 118, 500 and 577, from Vinyl Products, Ltd., Butter Hill, Carshalton, Surrey. To use the No. 116 grade it is sufficient to press it on a coin or other hard material, peel it away gently and bake in an oven for about twenty minutes at $170^{\circ} \mathrm{C}$. On cooling, it will have the consistency of stiff rubber, will be highly resistant to deformation and virtually insoluble. With the softer varieties the material may be painted or dabbed with the 'Vinagel' until a sufficient thickness is obtained, and then the original and its covering must be baked as before. Its great optical resemblance when cured to bone suggests that one of its most important biological uses lies in osteology, though it will be certain to be of service to sculptors, artists and museum technicians.

\section{Announcements}

WE regret to announce the following deaths:

Mr. S. F. Ashby, formerly director of the Imperial Mycological Institute, on March 6, aged seventy. nine.

Prof. E. P. Cathcart, C.B.E., F.R.S., emeritus professor of physiology in the University of Glasgow, on February 18.

Prof. J. L. Coolidge, emeritus professor of mathematics in Harvard University, aged eighty.

Prof. O. Diels, emeritus professor of chemistry in the University of Kiel, on March 7, aged seventyeight.

Dr. N. G. Horner, formerly editor of the British Medical Journal, on March 7, aged seventy-two.

OwING to the increasing activities of the Society of Dyers and Colourists (19 Piccadilly, Bradford 1), the post of editor and general secretary of the Society, held by Dr. C. J. W. Hooper, has been divided, with Dr. Hooper continuing as editor and technical officer. The new post of secretary of the Society is being filled by Mr. J. W. Nicholls, who until recently has been working in Newcastle upon Tyne as secretary and organizer of the Federation of Master Builders.

CHANGES in the chairmanship in research boards of the Department of Scientific and Industrial Research have been announced as follows: Building Research Board, Sir Herbert Manzoni, city engineer of Birmingham, in succession to Mr. W. K. Wallace, chairman since 1949; Food Investigation Board, Dr. R. Holroyd, director of research, Imperial Chemical Industries, Ltd., in succession to Sir Frank Engledow, chairman since 1947; Geological Survey Board, Sir Walter Drummond, deputy chairman of the National Coal Board, in succession to Sir Arthur Trueman, chairman since 1943, who has retired from the post owing to ill-health; Road Research Board, Mr. E. J. Powell, county surveyor of Glamorgan, in succession to Sir Frank Smith, chairman since 1946.

The United Steel Companies, Ltd., have recently endowed a fellowship for research in ferrous metal. lurgy at the University of Sheffield, and Dr. A. R. Entwisle, who for some time past has been engaged in metallurgical research in Sheffield, has been appointed as the first holder. Dr. Entwisle will study the effect of interstitial elements on the formation of martensite.

As in former years, a course in tropical hygiene for laymen will be held by the Ross Institute of Tropical Hygiene, London, during July 26-30. The course is for workers in the tropics holding posts which entail looking after the health and welfare of others. Morning sessions will be devoted to malaria and its control, and in the afternoons other tropical diseases and problems, such as hookworm, bilharzia, nutrition, housing and sanitation, and protection against heat will be dealt with. There is no fee for the course. Further information can be obtained from the organizing secretary, L. G. Ponsford, Ross Institute of Tropical Hygiene, London School of Hygiene and Tropical Medicine, Keppel Street (Gower Street), London, W.C.1.

Erratum. In the communication entitled "Possible Existence of a Transition Point between $\beta$ - and $\gamma$-Sulphur", by R. S. Bradley, Dr. N. H. Hartshorne and M. Thackray (Nature, February 27, p. 400), the legend on the ordinate of the graph should read "Log-rate (mm./hr.)". 